\title{
Penalaran Moral dan Perilaku Menyontek: Deskripsi Tingkatan serta Korelasinya pada Siswa
}

\author{
Friska Yuniar Nindi Pratiwi ${ }^{*}{ }^{1}$, Kusnarto Kurniawan ${ }^{2}$ \\ 1, 2 Program Studi Bimbingan dan Konseling, Universitas Negeri Semarang, Indonesia. \\ *) Corresponding author, $\fallingdotseq \mathrm{e}$-mail: friska9nindi@gmail.com
}

$\begin{array}{ccc}\text { Received: } & \text { Accepted: } & \text { Published: } \\ \text { 05 August 2021 } & \text { 15 October 2021 } & \text { 31 December 2021 }\end{array}$

\begin{abstract}
Based on the preliminary study, it's known that cheating behaviour is major problem for the education sector. The aim of this research is examine the correlation between moral reasoning and cheating behaviour of senior high school students. Current research is quantitative research with correlational method. 282 samples were selected using proportionate stratified random sampling technique. Moral reasoning variable were measured using psychological scale based on the level of moral reasoning according to Kohlberg's theory and cheating behaviour variable were measured using psychological scale based on cheating behaviour indicators. Data were analysed using Product Moment correlation technique. After analysing the data, the results revealed there is significant negative relationship between moral reasoning and cheating behaviour ( $r=-.265$, p $\sqsubset .05)$ among senior high school students indicating when moral reasoning is high then cheating behaviour is low, and vice versa. It is expected that the continuation of this research can find interventions to reduce cheating behaviour.
\end{abstract}

Keywords: Moral Reasoning, Cheating Behavior, Student

\begin{abstract}
Abstrak
Perilaku menyontek dengan berbagai macam bentuk masih menjadi salah satu masalah dalam dunia pendidikan.Tujuan kajian ini adalah untuk menentukan hubungan antara penalaran moral dengan perilaku menyontek siswa SMA. Jenis penelitian ini yakni penelitian kuantitatif dengan pendekatan korelasional. Sampel sebanyak 282 yang dipilih menggunakan teknik Proportionate stratified random sampling dari pupulasi. Variabel penalaran moral diukur menggunakan skala psikologis berdasar pada tingkatan penalaran moral menurut teori Kohlberg serta variabel perilaku menyontek diukur dengan skala psikologis yang berdasar pada indikator perilaku menyontek. Teknik analisis data menggunakan rumus korelasi Product Moment. Hasil kajian menunjukkan bahwa terdapat hubungan yang negatif antara penalaran moral dengan perilaku menyontek siswa SMA artinya semakin tinggi penalaran moral maka semakin rendah perilaku menyonteknya, begitupun sebaliknya. Hasil penelitian ini diharapkan dapat menjadi pedoman bagi Guru BK untuk membuat program tentang pencegahan perilaku menyontek pada siswa.
\end{abstract}

Kata Kunci: Penalaran Moral, Perilaku Menyontek, Siswa 


\section{PENDAHULUAN}

Permasalahan

menyontek

merupakan hal klasik yang hampir ditemui di semua jalur dan jenjang pendidikan, mulai dari tingkat dasar, menengah, maupun pendidikan tinggi. Namun, masyarakat masih menganggap perilaku menyontek sebagai perilaku yang wajar dilakukan serta sulit ditinggalkan oleh siswa. Maraknya permasalahan menyontek membuktikan gagalnya bukan hanya guru namun juga orang tua, administrator serta dewan pengurus sekolah dalam bersikap proaktif terhadap kecurangan akademik (Pujiatni \& Lestari, 2010). Hartanto (2012:11) mendefinisikan perilaku menyontek sebagai praktik kecurangan akademik dengan cara bertanya, memberi informasi, serta membuat catatan demi keuntungan dirinya sendiri.

Menyontek erat kaitannya dengan nilai moral, oleh karenanya apabila perilaku menyontek dianggap hal yang biasa untuk dilakukan dampaknya akan hilang nilai moral dalam bidang pendidikan khususnya. Hal itu dikarenakan dalam praktik menyontek mengabaikan aspek kejujuran serta usaha untuk mendapatkan hasil yang maksimal. Selain itu, menyontek tidak hanya merugikan diri sendiri namun juga orang lain. Alawiyah (dalam Hidyat \& Rozali, 2015) menyampaikan bahwa kerugian yang didapat bagi pelaku menyontek adalah tidak dapat mengukur kemampuan diri sendiri terhadap suatu materi yang telah dipelajari karena hasil yang ia dapat merupakan hasil yang tidak jujur, sedangkan untuk pihak yang dicontek/ peserta lain secara tidak langsung hak mereka telah direnggut.

Hartounian (2018) menyebutkan salah satu faktor pendorong siswa untuk melakukan aksi menyontek adalah moralitas. Moralitas memiliki tiga bagian yakni perilaku moral, perasaan moral serta penalaran moral. Dalam teori penalaran moral oleh Kohlberg, penalaran moral adalah pemikiran tentang masalah moral. Dari pemikiran itulah akan lahir sesuatu tindakan dalam suatu situasi. Kohlberg (dalam Mukhoyyaroh, 2012) menjelaskan penalaran moral sebagai pemikiran yang menjawab mengapa suatu hal dapat dikatakan baik atau buruk serta benar atau salah. Penalaran moral selanjutnya dibagi menjadi tiga tingkat, tingkat pertama yakni tingkat prakonvesional, kedua tingkat konvesional, serta yang terakhir tingkat pasca-konvesional. Mujahidah (2009) menyatakan pada usia remaja seharusnya penalaran moral siswa sudah sampai tahap konvesional dimana siswa harusnya sudah dapat mengikuti aturan-aturan kelompok, selain itu siswa juga seharusnya sudah dapat mempertimbangkan akibat dari perilaku menyontek. Namun faktanya masih banyak kasus menyontek yang membuktikan masih rendahnya pemahaman siswa terkait dengan nilai-nilai moral. Perlu dipahami bahwa pendidik memiliki tanggungjawab etis untuk mendorong siswa melakukan penilaian moral (McLeod-Sordjan, 2014).

Seperti halnya kasus menyontek yang ditemukan di SMA N 1 Kradenan, sejalan dengan yang dipaparkan Santrock 
siswa SMA tidak terkecuali Siswa SMA N 1 Kradenan yang seharusnya sudah memasuki tahap penalaran moral tingkat konvesional seharusnya sudah paham akan norma yang harus diikuti serta mewujudkan harapan sosial faktaya masih banyak yang melakukan kecurangan yang mana hal itu sangat bertolak belakang dengan teori yang ada. Berdasar pada hasil survey yang telah peneliti lakukan pada Siswa SMA N 1 bentuk menyontek yang paling umum adalah dengan cara bertanya kepada teman atau siswa lain, selain itu cara lain yang digunakan ialah dengan membawa catatan kecil, menuliskan catatan pada anggota tubuh serta membawa Lembar Kerja Siswa ke dalam ruang ujian. Lebih dalam peneliti mewawancarai guru BK SMA N 1 Kradenan yang mengugkapkan bahwa kasus menyontek mudah dijumpai pada siswa, beliau juga mengaku pada ujian akhir semester 2019/2020 dalam ruangan yang beliau awasi didapatkan tiga kasus menyontek yang dilakukan oleh siswa. Selain itu beliau juga menambahkan bahwa sering dijumpai aduan kasus dari guru mata pelajaran lain terkait ketidakjujuran siswa selama ujian atau ulangan. Ungkapan tersebut menjadi bukti bahwasanya menyontek masih permasalahan yang sering terjadi dibidang Pendidikan.

Beberapa riset yang peneliti temukan berkenaan dengan penalaran moral dan perilaku menyontek yang pertama, penelitian yang dilakukan oleh penelitain Dewi (2019) yang memaparkan terdapat hubungan yang negative antara antara variabel moral reasoning (penalaran moral) dengan academic dishonesty (perilaku menyontek) itu berarti semakin tinggi penalaran moral maka semakin rendah kemungkinan individu untuk menyontek pun sebaliknya, yang memebedakan penelitian Dewi dengan penelitin kali ini alah peneliti lebih melihat perilaku menyontek sebagai salah satu bentuk kecurangan akademik. Selanjutnya penelitian dari Afroh (2014) yang menunjukkan hasil yang sebaliknya yang menyatakan bahwa tidak ditemukan hubungan yang signifikan anatara penalaran moral dengan perilaku menyontek. Sejalan dengan pendapat Afroh, Buana \& Soetjiningsih (2019) memaparkan bahwa tidak ditemukan hubungan antara penalaran moral dengan perilaku kecurangan akademik pada mahasiswa. Adanya kesenjangan fakta dengan teori yang ada membuat peneliti tertarik untuk menganalisis lebih dalam hubungan antara penalaran moral dengan perilaku menyontek pada siswa SMA N 1 Kradenan.

\section{METODE}

Jenis kajian ini menggunakan pendekatan kuantitatif dengan desain korelasional. Teknik pengambilan sampel menggunakan Proportionate stratified random sampling. Setelah dilakukan perhitungan menggunakan rumus Isac and Michael menggunakan taraf kesalahan 5\% maka didapatkan banyaknya sampel sebanyak 94 responden pada masingmasing angkatan atau total 282 responden dari semua angkatan. 
Metode pengumpulan data yang digunakan ialah dengan memanfaatkan skala psikologis baik untuk mengukur variabel perilaku menyontek juga untuk mengukur variabel penalaran moral. Guna menyusun skala psikologi perilaku menyontek, peneliti mengacu pada indikator perilaku menyontek yang dipaparkan oleh Hartanto (2012). Item yang dibuat sejumlah 80 item yang terbagi menjadi dua jenis item favorable dan unfavorable. Sedangkan untuk menyusun skala psikologis penalaran moral mengacu pada tahap penalaran moral menurut teori Kohlberg. Item yang dibuat sejumlah 60 item yang terbagi menjadi dua jenis item favorable dan unfavorable. Skala psikologis perilaku menyontek dan penalaran moral disajikan dengan empat pilihan jawaban yaitu SS (Sangat Sesuai), S (Sesuai), TS (Tidak Sesuai), STS (Sangat Tidak Sesuai).

Uji coba instrumen dilakukan dengan melibatkan 50 responden dengan taraf signifikan $5 \%$ menggunakan rumus Product Moment yang perhitungannya dibantu dengan program Statistical Product and Services Solution (SPSS). Untuk skala perilaku menyontek sebanyak 9 item gugur karena koefesien korelasi item hasilnya lebih kecil dari 0,279 sehingga jumlah item yang valid sebanyak 71 item. Sedangkan untuk skala penalaran moral sebanyak 12 item gugur karena koefesien korelasi item hasilnya kurang dari 0,279 sehingga total item skala penalaran moral yang valid sebanyak 47 item. Kedua skala psikologi memiliki kriteria reliabilitas yang tinggi dengan skor 0,935 untuk skala psikologi perilaku menyontek dan skor 0,919 untuk skala psikologi penalaran moral. Perhitungan relibalitas dilakukan menggunakan rumus Alpha dengan bantuan program Statistical Product and Services Solution (SPSS). Teknik analisis data yang digunakan adalah analisis diskriptif untuk memberikan gambaran umum dan uji korelasi Product moment untuk membuktikan hubungan antara variabel penalaran moral dengan variabel perilaku menyontek yang sebelumnya dilakukan uji asumsi klasik terlebih dahulu yakni uji normalitas dan uji linieritas sebagai syarat dilakukanya uji korelasi.

\section{HASIL TEMUAN}

Hasil penelitian disajikan dalam dua bagian yang pertama hasil analisis diskriptif kuantitatif yang mendiskripsikan tingkat perilaku menyontek dan tingkat penalaran moral siswa SMA N 1 Kradenan, selanjutnya hasil analisis korelasi yang mencari tahu hubungan antara variabel penalaran moral dan variabel perilaku menyontek.

Hasil analisis diskriptif untuk perilaku menyontek siswa SMA $N$ Kradenan secara ringkas dirangkum pada tabel berikut.

Tabel 1. Tingkatan perilaku menyontek

\begin{tabular}{ccc}
\hline Kategori & Frekuensi & Presentase \\
\hline Sangat Tinggi & 38 & $15 \%$ \\
Tinggi & 148 & $52 \%$ \\
Sedang & 94 & $33 \%$
\end{tabular}




$\begin{array}{ccc}\text { Rendah } & 2 & 1 \% \\ \text { Sangat Rendah } & 0 & 0 \%\end{array}$

Berdasar pada Tabel 1 maka didapatkan informasi bahwa perilaku menyontek di SMA N 1 Kradenan berkisar pada kategori rendah hingga sangat tinggi selain itu dapat dianalisis bahwa mayoritas siswa SMA N 1 Kradenan memiliki tingkat perilaku menyontek tinggi dengan presentase sebesar $52 \%$.
Selanjutnya, analisis diskriptif untuk penalaran moral siswa SMA $\mathrm{N} 1$ Kradenan yang merujuk pada tingkat penalaran moral oleh teori Kohlberg, maka tingkat penalaran moral siswa SMA N 1 Kradenan mayoritas berada pada tahap konvesional, seperti yang dirangkum pada Tabel 2 berikut:

Tabel 2. Tingkat penalaran moral

\begin{tabular}{cc}
\hline Tingkat penalaran moral & Presentase \\
\hline Pra-Konvesional & $32 \%$ \\
Konvesioanal & $35 \%$ \\
Pasca-Konvesioanal & $33 \%$ \\
\hline
\end{tabular}

Selanjutnya peneliti melakukan uji korelasi untuk mengetahui hubungan antara variabel penalaran moral dengan perilaku menyontek. uji korelasi menggunakan rumus Product Moment. Namun sebelum menguji korelasi dibutuhkan uji normalitas dan uji linieritas data untuk memenuhi asumsi dasar analisis korelasi.

Uji normalitas menggunakan teknik One-Sample Kolmogorov-Smirnov Test yang dalam perhitungannya dibantu dengan program Statistical Product and Services Solution (SPSS). Setelah dilakukan uji didapatkan hasil bahwa kedua variabel memiliki data yang berdistribusi normal dengan skor 0,608 untuk variabel perilaku menyontek dan 0,069 untuk variabel penalaran moral. Uji linieritas menggunakan metode lack of fit dengan melihat nilai deviation of linierity. Setelah dilakukan uji didapatkan hasil nilai deviation of linierity 0,733 yang mana kedua variabel dinyatakan memiliki hubungan yang linier.

Setelah data dinyatakan berdistribusi normal dan linier, barulah dapat dilakukan uji korelasi. Uji korelasi dilakukan dengan rumus Product Moment menggunakan indeks Pearson. Uji korelasi memanfaatkan program Statistical Product and Services Solution (SPSS) dengan hasil pada Tabel 3.

Tabel 3. Hasil Analisis korelasi

\begin{tabular}{lllc}
\hline Variabel & $\mathbf{R}$ & $\mathbf{p}$ & Katerangan \\
\hline $\begin{array}{l}\text { Penalaran Moral dengan Perilaku } \\
\text { Menyontek }\end{array}$ & $-0,265$ & 0,05 & Negatif- Signifikan \\
\hline
\end{tabular}


Berdasar pada Tabel 3, ditunjukkan bahwa nilai signifikasi sebesar -0,265, maka hipotesis yang menyatakan ada hubungan yang signifikan antara penalaran moral dengan perilaku menyontek di SMA N 1 Kradenan diterima. Karena nilai Pearson Correlation menunjukkan tanda negative (-) hal itu berarti terdapat hubungan yang negatif antara variabel penalaran moral dengan perilaku menyontek.

\section{PEMBAHASAN}

Berdasarkan data hasil kajian perilaku menyontek siswa SMA $\mathrm{N} 1$ Kradenan berada pada kategori tinggi. Hal ini dapat dianalisis bahwa banyak siswa yang sudah mengesampingkan nilai-nilai kejujuran dan usaha untuk mendapat hasil yang optimal. Tingginya perilaku menyontek siswa juga mencerminkan bahwa banyak siswa yang memanipulasi prestasinya karena hasil yang didapatkan tidak bersumber murni dari pemikiranya. Semua orang menyepakati bahwa menyontek merupakan perbuatan tidak bermoral, namun hal ini ternyata masih sulit ditinggalkan oleh para siswa (Makridis \& Englander, 2020). Sejalan dengan hal itu Mujahidah (2009) menyatakan beberapa faktor yang melatarbelakangi perilaku menyontek siswa yakni faktor personal diantaranya self-esteem dan need for approval serta rasa percaya diri, faktor situasional termasuk peluang untuk menyontek, tekanan mendapat nilai yang tinggi dari pihak eksternal juga internal, ketidaksiapan mengikuti ujian juga pengaruh teman sebaya, serta faktor terakhir berkenaan dengan faktor demografi termasuk usia, jenis kelamin dan moralitas yang berbeda antara satu siswa dengan siswa lainnya.

Selanjutnya didapatkan hasil bahwa mayoritas siswa SMA N 1 Kradenan memiliki penalaran moral yang berada dalam tahap konvesional. Pada tingkat konvesional seperti yang dipaparkan oleh Santrock (2003) individu pada tahap konvesional sudah dapat mengiternalisasi aturan yang berlaku di masyarakat seperti aturan yang ditatapkan oleh orang tuanya juga masyarakat. Temuan ini sejalan dengan paparan Santrock (2007) yang menyebutkan bahwa umumnya remaja memiliki tingkat penalaran moral konvesional. Namun ditemukan juga perbedaan tingkat penalaran moral pada siswa. Perbedaan tingkat penalaran moral pada tiap-tiap siswa dikarenakan adanya perbedaan konsep moral pada masingmasing siswa. Konsep moral biasanya didasari pada perbedaan pendidikan yang diberikan oleh pihak eksternal seperti oleh orang tua, guru atau dalam kelompok sosial siswa yang berbeda.

Berikutnya setelah dilakukan uji korelasi didapatkan hasil bahwa terdapat hubungan yang negatif antara perilaku menyontek dengan penalaran moral. Hal ini berarti penalaran moral memiliki hubungan yang mempengaruhi perilaku menyontek pada siswa. Temuan ini senada dengan hasil penelitian Dewi (2019) bahwa terdapat hubungan yang negatif antara penalaran moral dengan ketidakjujuran akademik. Hal itu berarti semakin tinggi penalaran moral siswa maka semakin rendah ketidak jujuranak ademiknya. Penalaran moral 
merupakan kemampuan seseorang untuk memutuskan suatu hal dapat dikatakan benar atau salah berdasar pada pada pemikiran setiap individu. Dikatakan bahwa penalaran moral juga berkaitan dengan perilaku moralnya, dijelaskan oleh Grenne (dalam Mbokochena et al., 2014). Hal tersebut dikarenakan penalaran moral seseorang akan dijadikan pedoman untuk berperilaku, oleh karena itu individu yang memiliki penalaran moral yang tinggi akan tercermin pada perilakunya yang sejalan dengan nilai moral yang berlaku di masyarakat. Oleh karena itu apabila dikatikan dengan perilaku menyontek yang bertentangan dengan nilai norma yang berlaku, siswa yang memiliki penalaran moral yang tinggi harusnya tidak menunjukkan perilaku menyontek dan lebih menunjukkan perilaku terpuji yang mana sesuai dengan aturan yang berlaku di lingkungan.

Namun peneliti juga menemukan adanya hubungan atau korelasi yang rendah antara variabel penalaran moral dengan perilaku menyontek, sejalan dengan pendapat Papalia, Olds, dan Feldman (dalam Machmuroch et al., 2013) yang memaparkan bahwa tidak ada kejelasan antara hubungan penalaran moral dengan perilaku moral, itu berarti belum tentu individu yang memiliki moral tinggi selaras dengan perilaku moralnya yang tinggi pula atau dengan kata lain penalaran moral bukanlah faktor yang kuat untuk mendorong siswa agar melakukan tindakan menyontek atau tidak. Begitu juga dengan menyontek, meskipun masyarakat beranggapan bahwa perilaku menyontek merupakan perbuatan yang tidak sejalan dengan norma yang ada namun bukan berarti setiap individu juga berfikir demikian, hal ini karena individu dengan tingkat penalaran moral konvesioanal baru menginternalisasi sebagian anturan atau standar yang berlaku di masyarakat.

Friyatmi (2011) dalam paparanya menyebutkan bahwa banyak faktor lain yang mempengaruhi perilaku menyontek diantaranya penguasaan materi, cara belajar, success story, konsep diri, motif personal, situasi dan faktor sosial yang apabila dikelompokkan akan terbentuk dua faktor yakni faktor internal dan faktor eksternal. Diantara faktor diatas yang memiliki pengaruh besar terhadap perilaku menyontek ialah faktor penguasaan materi disusul oleh cara belajar sebagai faktor internal kedua yang berkontribusi besar.

Berdasarkan penjelasan tersebut dapat disimpulkan bahwa salah faktor yang mempengaruhi perilaku menyontek adalah penalaran moral. Namun penalaran moral bukanlah faktor utama yang mendorong perilaku menyontek pada siswa. Berdasarkan kajian Love, dkk bahwa faktor lain yang mempengaruhi perlaku menyontek yaitu faktor internal seperti kepercayaan diri, etika professional, keadilan, rasa takut serta rasa bersalah, lalu faktor eksternal termasuk nilai, waktu dan tekanan tugas (Smith et al., 2002).

Salah satu layanan bimbingan dan konseling yang dapat diberikan oleh Guru BK/ Konselor sekolah dalam meningkatkan penalaran moral siswa, sehingga dapat mengurangi dan mengentaskan perilaku menyontek adalah layanan bimbingan 
kelompok. Hal ini dikarenakan layanan bimbingan kelompok dapat menumbuhkan rasa percaya diri dan secara terbuka mengungkapkan apa yang dirasakan dan dialaminya secara terbuka dengan mengaktifkan dinamika kelompok sesuai dengan topik yang dibahasa, sehingga Guru BK/Konselor sekolah dapat mengetahui sejauh mana penalaran moral dan aktivitas belajar siswa yang terjadi dalam mencegah mauoun mengentaskan perilaku mencontek (Pohan \& Indra, 2020) (Kurniasari et al., 2021).

Kajian ini telah dilaksanakan dengan sebaik mungkin, namun tentunya masih memiliki keterbatasan, seperti: 1) penelitian ini dilaksanakan pada masa pandemi Covid-19 sehingga hanya memanfaatkan google form untuk menggambilan data dari sampel oleh karenanya besar kemungkinan terjadinya faking good oleh responden karena peneliti tidak dapat bertatap muka langsung dengan responden, namun untuk meminimalisir permasalahan tersebut telah peneliti beri petunjuk pengisian angket dengan jelas dan ringkas, kajian ini hanya sebatas melihat perilaku menyontek dari segi penalaran moral siswa oleh karenanya masih ada faktor lain yang menyebabkan perilaku menyontek yang belum dibahas secara lebih mendalam dan rinci, sampel yang digunakan hanya sebatas siswa yang berasal dari SMA N 1 Kradenan sehingga belum dapat digeneralisasikan secara keseluruhan di sekolah yang lain.

\section{SIMPULAN}

Perilaku menyontek siswa SMA N 1 Kradenan berada pada kategori tinggi dan penalaran moral Siswa SMA N 1 Kradenan berada pada tingkat kedua atau pada tingkat konvensional. Selain itu terdapat hubungan yang negatif antara penalaran moral dengan perilaku menyontek pada Siswa SMA N 1 Kradenan, hal ini berarti semakin tinggi tingkat penalaran moral maka semakin rendah perilaku menyonteknya begitu pula sebaliknya apabila tingkat penalaran moralnya rendah kecenderungan siswa untuk menyontek semakin tinggi. Namun penalaran moral bukanlah faktor terkuat yang membentuk perilaku menyontek pada siswa, masih ada faktor lain yang belum dikaji dalam penelitian ini baik faktor internal maupun eksternal. Guru BK dapat memberikan layanan bimbingan kelompok atau bimbingan klasikal dengan topik menyontek atau kiat-kiat belajar untuk mereduksi perilaku menyontek serta untuk meningkatkan kemampuannya sesuai dengan potensi yang dimilikinya secara optimal.

\section{UCAPAN TERIMA KASIH}

Terimakasih kepada Kepala SMA N 1 Kradenan serta Guru BK SMA N 1 Kradenan yang telah memeberikan izin dan membantu peneliti selama proses penelitian. Terima kasih pua kepada seluruh siswa SMA N 1 Kradenan yang bersedia meluangkan waktunya untuk mengisi angket penelitian. 
DAFTAR PUSTAKA

Afroh, K. (2014). Hubungan antara penlaran moral dengan perilaku menyontek pasa siswa di Madrasah Tsanawiyah Negeri Gondowulung Bantul $\square$. UIN Sunan Kalijaga Yogyakarta.

Buana, Z. P., \& Soetjiningsih, C. H. (2019). Penalaran moral dan perilaku kecurangan. Perseptual, 4(1), 65-79.

Friyatmi. (2011). Faktor-faktor penentu perilaku mencontek di kalangan mahasiswa fakultas ekonomi UNP. TINGKAP, VII(2), 173-188.

Hartounian, P. (2018). The relationship between cognitive moral development and attitudes toward Academic cheating of Armenian high school students at an Armenian private school in Southern California. Pepperdine University.

Hidyat, M. T., \& Rozali, Y. A. (2015). Hubungan antara self efficacy dengan perilaku sehat. Journal Psikologi, 13 (1), 85-89.

Kurniasari, P., Jafar, M., Sunawan, S., \& Muhammadiyah Magelang, U. (2021). Impact of group counseling with cognitive restructuring techniques to reduce cheating and increase self efficacy. Jurnal Bimbingan Konseling, 10(1), 61-68. https://doi.org/10.15294/JUBK.V9I1.45 488.

Machmuroch, K, T. M. V., \& Yusuf, M. (2013). Hubungan antara moral judgment maturitydengan perilaku menyontek pada siswa Kelas X SMA Negeri 8 Surakarta. Jurnal Ilmiah Psikologi Candrajiwa, 2, 131-143.

Makridis, O., \& Englander, F. (2020).
Normative revisionism about student cheating. Journal of Academic Ethics $2020 \quad 19: 1, \quad 19(1), \quad 1-23$. https://doi.org/10.1007/S10805-02009384-Z.

Mbokochena, E., Mudzengerere, F. H., \& Chikwiri, E. (2014). Exploring the link between moral reasoning and behavioral action among young children in Zimbabwean. Journal for Educational Studies, 7(August), 1-6.

McLeod-Sordjan, R. (2014). Evaluating moral reasoning in nursing education. Nursing Ethics, 21(4), 473-483. https://doi.org/10.1177/0969733013505 309.

Mujahidah. (2009). Perilaku menyontek laki-laki dan perempuan: Studi Meta Analisis. Jurnal Psikologi, II(2), 177199.

Mukhoyyaroh, T. (2012). Penalaran moral remaja perempuan ditinjau dari konformitas dan lingkungan tempat tinggal. Jurnal Penelitian Psikologi, 3(1), 355-366.

Pohan, R. A., \& Indra, S. (2020). Efektivitas layanan bimbingan kelompok dalam meningkatkan kegiatan merespon pembelajaran. Islamic Counseling : Jurnal Bimbingan Dan Konseling Islam, 4(1), 17-30. https://doi.org/10.29240/JBK.V4I1.128 0 .

Pujiatni, K., \& Lestari, S. (2010). Studi kualitatif perilaku menyontek pada mahasiswa. Jurnal Penelitian Humaniora, 11(2), 103-110. 
Rahmadani, Feby. (2017). Hubungan antara penalaran moral dengan perilaku menyontek pada Siswa SMA Negeri 3 Tualang.Skripsi. Riau: UIN Sultan Syarif Kasim Riau.

Santrock, J. W. (2007). Remaja. Edisi 11 Jilid 1. Jakarta: Erlangga.

Santrock, J. W. (2007). Adolescence. Edisi keenam. Jakarta: Erlangga.

Smith, K. J., Davy, J. A., Rosenberg, D. L., \& Timothy Haight, G. (2002). A structural modeling investigation of the influence of demographic and attitudinal factors and in-class deterrents on cheating behavior among accounting majors. Journal of Accounting Education, 20(1), 45-65. https://doi.org/10.1016/S07485751(01)00026-4. 